\title{
Laboratory investigations on the effect of prey size and concentration on the feeding behaviour of Sardina pilchardus
}

\author{
Susana Garrido ${ }^{1, *}$, Ana Marçalo ${ }^{1,2}$, Juan Zwolinski ${ }^{1}$, Carl D. van der Lingen ${ }^{3}$ \\ ${ }^{1}$ Instituto Nacional de Investigação Agrária e das Pescas (INIAP/IPIMAR), Avenida de Brasília, 1449-006 Lisboa, Portugal \\ ${ }^{2}$ INIAP/IPIMAR, CRIP Sul, Avenida 5 de Outubro s/n, 8700-305 Olhão, Portugal \\ ${ }^{3}$ Marine and Coastal Management, Private Bag X2, Rogge Bay 8012, South Africa
}

\begin{abstract}
Laboratory experiments were conducted to study the effects of different prey types and concentrations on the feeding behaviour of the Iberian sardine Sardina pilchardus. Known concentrations of different prey types (both single prey type and a mixture of prey types) were provided to a shoal of sardines acclimated to laboratory conditions and their feeding behaviour was observed. Data on feeding mode choice, feeding selectivity and filtration efficiency were collected, and clearance rates for different prey types and sizes were estimated. Sardines use 2 feeding modes and switch between them depending on prey size. Filter-feeding was used to capture prey $\leq 724 \mu \mathrm{m}$ and particulate feeding to capture prey $\geq 780 \mu \mathrm{m}$; therefore the feeding mode switch occurs within these limits. Sardines are able to feed on nanoplankton and can retain prey items as small as $4 \mu \mathrm{m}$, and filtration efficiency increases from $20 \%$ at this prey size to close to maximum for prey $>200 \mu \mathrm{m}$. Sardines show selective feeding, preferentially ingesting fish eggs compared to other prey types (even larger fish larvae) when fed cultured, mixed prey assemblages and selecting copepods and decapods over other zooplankton prey when fed wild-collected, mixed prey assemblages. Clearance rates were generally low compared to other clupeids, arising from the smaller mouth gape and lower swimming speed of this species. Results obtained from this study suggest that filter-feeding is the dominant feeding mode of $S$. pilchardus and that it is able to efficiently utilize microplankton prey, and corroborate previous dietary studies indicating that small zooplankton and chain-forming diatoms dominated stomach contents.
\end{abstract}

KEY WORDS: Sardina pilchardus · Planktivorous fish · Feeding behaviour · Filter-feeding · Particulate-feeding

Resale or republication not permitted without written consent of the publisher

\section{INTRODUCTION}

The Iberian sardine Sardina pilchardus (Walbaum, 1792) is the main target of the purse-seine fishery off Portugal and Spain, with average annual landings of 100000 t during the last decade (ICES 2006). High fluctuations in both population size and catches off the Iberian coast have stimulated several studies of this commercially important resource (e.g. Borges et al. 2003, Stratoudakis et al. 2003, Guisande et al. 2004). Studies of the trophic ecology of sardines (Bode et al.
2003, 2004, Costa \& Garrido 2004) have followed the assumption that the feeding ecology of small pelagic fishes is a key factor in regulating their abundance and distribution (e.g. Mathisen et al. 1978, Parrish et al. 1981, Schwartzlose et al. 1999).

Previous studies based on stomach content (Varela et al. 1988, 1990, Garrido 2003, Cunha et al. 2005) and stable isotope analyses (Bode et al. 2003, 2004) have shown that sardines have a highly diverse diet, dominated in terms of biovolume by micro- and mesozooplankton prey. High numbers of phytoplankton cells, 
mainly chain-forming diatoms and dinoflagellates, usually occur in sardine stomach contents, but these generally represent $<10 \%$ of total prey biovolume (Cunha et al. 2005). The correspondence between the ambient food environment and stomach contents suggest that sardines are essentially filter-feeders whose diet reflects plankton composition (Varela et al. 1990, Bode et al. 2003). However, although stomach content analysis is an essential tool to study seasonal and geographical variability in the diet of planktivorous fish, it is insufficient to address important aspects related to feeding behaviour, which may clarify the relationship between fish population dynamics and food availability.

Knowledge of the feeding behaviour of planktivorous fish allows the identification and recognition of favourable feeding conditions/environments for the fish, the potential niche separation between different co-habiting fish species, and the estimation of their impacts on plankton communities. Several laboratory experiments with planktivorous small pelagic fish species have shown that feeding behaviour and ingestion rates depend primarily on prey size and concentration (e.g. Leong \& O'Connell 1969, Janssen 1976, Friedland et al. 1984, James \& Findlay 1989, Gibson \& Ezzi 1990, van der Lingen 1994). Planktivorous fish generally feed through filter-feeding, particulate-feeding or both (Lazzaro 1987), and it is assumed that if an individual alters its feeding behaviour in response to changing prey conditions, that change will result in a greater net energy gain (Gibson \& Ezzi 1992).

The objective of this work was to study the feeding behaviour of Sardina pilchardus, specifically to characterize its feeding mode, swimming velocity and ingestion rates for different phyto-, zoo- and ichthyoplankton prey types and concentrations. To meet this objective several laboratory experiments were performed that closely followed the protocol used by James \& Findlay (1989) and van der Lingen (1994) for cape anchovy Engraulis encrasicolus (formerly E. capensis; Grant \& Bowen 1998) and sardine Sardinops sagax, respectively. Experiments aimed at identifying and/or clarifying aspects of sardine feeding behaviour, including (1) a determination of whether Sardina pilchardus shows preferential feeding modes that are adapted to specific environmental feeding conditions, (2) quantification of the filtering efficiency (the efficiency of the filtering apparatus in retaining particles, expressed as a percentage of the estimated maximum clearance rate), particularly for small sized prey, which will allow definition of prey length spectra available to sardines, (3) estimation of the feeding rates for different prey types, an essential input term for future bioenergetics studies, and (4) whether $S$. pilchardus exhibits feeding selectivity, which is crucial for estimating the impact of this species on plankton communities.

\section{MATERIALS AND METHODS}

Acclimatization. Iberian sardines were captured in June 2003 by a commercial purse-seiner operating from the port of Olhão in southern Portugal. Details regarding capture and transfer techniques used are given by Peleteiro et al. (2004). The fish were transported to the Aquaculture Station of Olhão (IPIMAR) in $300 \mathrm{l}$ plastic covered tanks, and there were transferred into $1500 \mathrm{l}$ circular tanks supplied with a continuous flow of $100 \mu \mathrm{m}$ sand-filtered sea water at ambient temperature $\left(17.9 \pm 0.6^{\circ} \mathrm{C}\right)$ and salinity (37). Sardines were acclimated to laboratory conditions for 4 mo prior to the onset of experiments, and were fed twice-daily with dry pellets (1 $\mathrm{mm}$ diameter 'Aquasoja' pellets) at an estimated daily ration of 1 to $2 \%$ total fish mass.

Food types. Both cultured and wild plankton were used in a total of 24 experiments, 18 of which used single prey types and 6 of which used combinations of different prey types. Cultured zooplankton included Brachionus plicatilis and Artemia salina (nauplii to adults), and cultured phytoplankton included the diatom Skeletonema costatum (single cells only) and the chlorophyte Tetraselmis suecica. Additionally, eggs and larvae of seabream Sparus aurata and sole Solea senegalensis cultured at the Aquaculture Station were fed to the sardines. Wild plankton was collected off the port of Olhão using 53 and $20 \mu \mathrm{m}$ WP2 drift nets trawled for $30 \mathrm{~min}$ to $1 \mathrm{hr}$; collected plankton was then transported to the laboratory and immediately used in experiments.

To determine the prey length at which sardines changed from filter- to particulate-feeding, a set of 6 experiments using the same initial density of either Brachionus plicatilis or Artemia salina of successively increasing length were performed, assuming that the potential transition would occur within the range of 200 to $1000 \mu \mathrm{m}$. In order to study the effect of prey density on sardine feeding behaviour and ingestion rates, and to assess whether sardines filter-feed on high densities of large prey items, fish eggs were added to the experimental tank at 3 different initial concentrations. Experiments were done to (1) examine whether sardines are able to feed selectively when offered a mixed assemblage of prey and (2) compare ingestion rates of sardine on particular prey items offered as the only prey type and as part of a mixed prey assemblage. To achieve these objectives experiments were conducted using mixed assemblages of both cultured (Expts 19-22, see Table 2) and wild (Expts 23-24, see Table 3) plankton. These assemblages comprised both small (assumed to elicit a filter-feeding response) and large (assumed to elicit a particulate-feeding response) prey items.

Experimental setup. We studied the feeding behaviour of a small group of sardines following the intro- 
duction of known concentrations of different food types into the tank (van der Lingen 1994). Experiments were recorded using a Sony VX 1000 digital video camera mounted $3 \mathrm{~m}$ above the tank. Changes in food concentration during an experiment were determined through sampling at regular intervals. Groups of 14 sardines of the same length class $(19.3 \pm 1.9 \mathrm{~cm}$ total length) were transferred to a $530 \mathrm{l}$ fibreglass experimental tank and acclimated there for $2 \mathrm{wk}$, including a $4 \mathrm{~d}$ period before each set of experiments during which fish were not fed. With the $4 \mathrm{~d}$ starvation period we tried to standardize the hunger state (without compromising their condition). The tank had a flat acrylic bottom marked with grid lines spaced $10 \mathrm{~cm}$ apart that were used as a reference for video recording (see below). In order to avoid habituation, each school was only used for 10 consecutive experiments before being replaced (van der Lingen 1994).

At the start of each experiment the water supply to the tank was switched off (experiments were performed with no water flow) and the fish were filmed for $15 \mathrm{~min}$ to determine non-feeding behaviour and swimming speeds. A known concentration of food contained in $5 \mathrm{l}$ of water was then added to the tank, while a porous air tube placed around the inner tank perimeter was activated for 3 min to promote a homogeneous distribution of prey within the tank. Immediately after mixing, water samples were collected to determine prey density at the beginning of the experiment $(t=0)$, and samples were subsequently collected every $10 \mathrm{~min}$ during the first hour and every 30 min thereafter until the end of the experiment.

The concentration of zoo- and ichthyoplankton prey in the tank was measured at each sampling time by taking 5 replicate samples using a PVC sampling tube that fitted into a $200 \mu \mathrm{m}$ mesh-bottomed cup and sampled a volume of 0.589 l. Phytoplankton prey concentration in the tank was measured by collecting 3 replicates of $250 \mathrm{ml}$. Prey items in each replicate sample were counted under a stereoscope ( $\times 63$; for zoo- and ichthyoplankton), an inversion microscope $(\times 400$; for natural phytoplankton) or a Coulter Counter EPICS XL (for cultured phytoplankton). Food items were either counted immediately or were preserved in $4 \%$ buffered formalin for later examination. Thirty individual food particles were measured (major and minor axes) for each experiment to determine average particle size and to estimate mean prey biovolume by assuming the closest geometric shape.

Analyses of video recordings taken during experiments were performed to determine feeding mode (whether filter- or particulate-feeding) used by sardines and fish swimming speed. A second video camera positioned close to the tank was used to determine the fish mouth gape and feeding bout duration during 2 experiments of each feeding mode (Expts 6, 8, 15 and 17; see Table 1) in a total of 78 feeding bout durations measured, and it was assumed that the values obtained were representative of each feeding mode. The average feeding bout duration was calculated by counting the number of frames sardines spent with their mouths open in the course of the experiments, and the time spent with the mouth closed between 2 successive feeding acts was also determined. Swimming speed was determined by counting the number of frames an individual sardine took to completely cross a grid line, and was recorded as body lengths per second $\left(\mathrm{bl} \mathrm{s}{ }^{-1}\right)$. Sardines whose path deviated more than $20^{\circ}$ during a swimming speed measurement were excluded. We made 30 measurements of swimming speed for each time interval between successive samplings of the food concentration, excluding the first 3 min after subsampling since this could have interfered with feeding behaviour and stressed the sardines.

The duration of the experiments was pre-determined as $1.5 \mathrm{~h}$ for experiments using zoo- and ichthyoplankton prey and $4.5 \mathrm{~h}$ for experiments using phytoplankton prey, unless sardines had completely removed prey and ceased feeding before this time.

Data analysis. Food concentration was tested for an exponential decrease with time using generalized linear models (GLM; Venables \& Ripley 2002), as: $s$ (concentration) $=\beta 0+\beta 1$ (time) where $s$ is the logarithm link function and concentration follows either a Poisson or negative binomial distribution. Initial prey concentration was obtained as the exponential of the model intercept $\beta 0$. The estimated slope parameter $\beta 1$, is then equivalent to the instantaneous grazing rate $g$ defined by Durbin \& Durbin (1975). Testing for differences in $g$ according to food types and experiments was done by deviance analysis at a significance level of $\mathrm{p}<0.05$. Statistical analysis was performed using the open source software R 1.9 (R Development Core Team 2005).

The clearance rate $F$ or volume swept clear (Harvey 1937) is calculated from the equation: $F=V g / N$ (l fish ${ }^{-1} \mathrm{~min}^{-1}$ ), where $V=$ water volume in the tank and $N=$ number of fish in the tank. The clearance rate represents the volume of water from which prey would have to have been removed to account for the measured decline in food concentration. The clearance rate for each experiment in which sardines used filter-feeding was compared to the maximum clearance rate in order to assess filtration efficiency. Maximum clearance rate was calculated from: $F_{\max }=s w \mathrm{Mg} M o$, where $s w=$ swimming speed $\left(\mathrm{cm} \mathrm{s}^{-1}\right), M g=$ mouth gape $\left(\mathrm{dm}^{2}\right)$ and $M o=$ percentage of time spent with mouths open (\%). The comparison of $F$ with $F_{\max }$ is a 
measure of the ability to retain food particles, and when $F=F_{\max }$ it is assumed that all the particles in the water passing through the gill rakers are retained, and that filtering efficiency is $100 \%$. Initial prey biovolume was calculated by multiplying the initial prey concentration by the average prey biovolume.

\section{RESULTS}

\section{Feeding modes}

Before the introduction of food to the experimental tank, sardines swam around continuously in a loose shoal, with a mean $( \pm$ SD) swimming speed of 0.93 $( \pm 0.23) \mathrm{bl} \mathrm{s}^{-1}$, equivalent to $18.1( \pm 4.5) \mathrm{cm} \mathrm{s}^{-1}$ (Fig. 1). The introduction of food items in all experiments elicited a feeding response, characterized by an increase in swimming speed and the initiation of filteror particulate-feeding, depending on prey size (Table 1). $M g$ while feeding was determined as 0.005 $( \pm 0.001) \mathrm{dm}^{2}$.

Sardines used filter-feeding when single phytoplankton cells and zooplankton of a size $<780 \mu \mathrm{m}$ were introduced into the tank. During this feeding mode fish engulf a volume of water containing food organisms and do not appear to visually select prey. Swimming speed when filter-feeding remained constant during the entire experiment and had an average $( \pm S D)$ value of $23.0( \pm 7.6) \mathrm{cm} \mathrm{s}^{-1}$. In addition to swimming faster than non-feeding fish, filter-feeding sardine schooled tightly and swam with their mouths held agape and opercula widely flared. Average feeding bout duration when filter-feeding was $0.500( \pm 0.258) \mathrm{s}$, and fish kept their mouths open on average for $52 \%$ of the whole experimental duration.

Sardines used particulate-feeding in every experiment where prey $>780 \mu \mathrm{m}$ were offered, which included large Artemia salina, cultured fish eggs and larvae, and wild

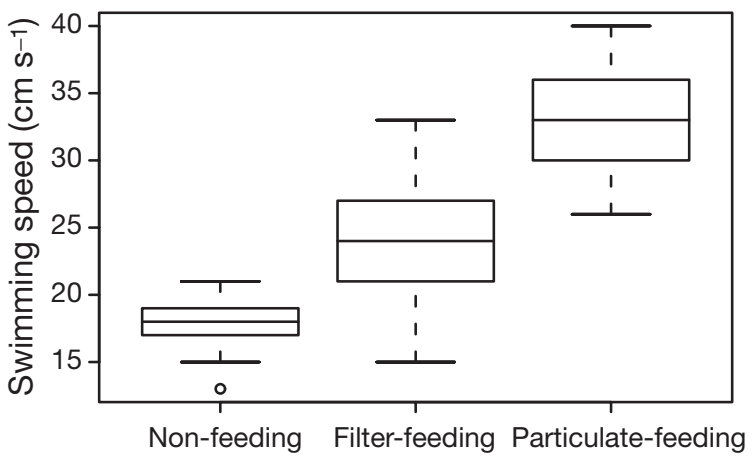

Fig. 1. Sardina pilchardus. Swimming speeds during nonfeeding, filter-feeding and particulate-feeding; the median, 1st and 3rd quartile, and range of observed values for each activity type are shown zooplankton assemblages. This feeding mode was characterized by the visual detection and attack on single prey items, and a higher increase in swimming speed after the introduction of food compared to that observed for filter-feeding fish (Fig. 1). There was also higher between-experiment variability in swimming speed while filter-feeding than while particulate-feeding. Swimming speed by particulate-feeding fish decreased slightly in the course of the experiments and had an average $( \pm S D)$ value of $30.0( \pm 9.0) \mathrm{cm} \mathrm{s}^{-1}$. When particulate-feeding, sardines dispersed from the shoal and aligned themselves towards prey items, with frequent turns and changes of direction being observed. In contrast to filter-feeding the opercula were only slightly flared, and feeding bout duration was shorter than during filter feeding, with an average value of $0.135( \pm 0.055)$ s. Additionally, the period between particulate-feeding acts was more variable than for filter-feeding, depending on the selection of other prey items. Fish all used the same feeding mode during a given experiment, and the transition between filter- and particulate-feeding was not gradual (see next section).

\section{Filtration efficiency and clearance rates}

Sardines were able to retain particles as small as 4 to $15 \mu \mathrm{m}$ (corresponding to single-cells of the diatom
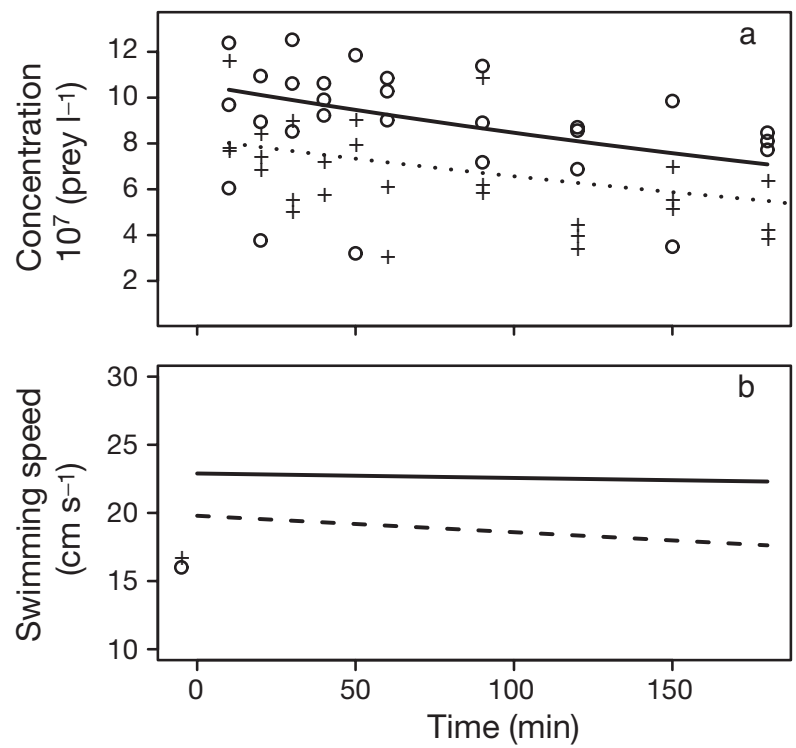

Fig. 2. Sardina pilchardus. Change in (a) food concentration and (b) swimming speed with time, for 2 experiments. Iberian sardines were filter-fed on cultured phytoplankton: Tetraselmis suecica (+, dashed line) and Skeletonema costatum (O, solid line). Food concentration decrease was modelled by GLM, the slope of the fitted lines is the instantaneous grazing rate. Swimming speed vs. time was fitted by linear regression and the symbols $(+, \circ)$ represent the non-feeding average swimming speed prior to the addition of food 
Table 1. Sardina pilchardus. Feeding experiments in which single prey types were used. Mean prey length ( $\mu$ m), experiment number (Expt), initial concentration (ic; number of prey $\mathrm{l}^{-1}$ ), dominant feeding mode (Mode; $\mathrm{f}$ indicates filter-feeding and $\mathrm{p}$ indicates particulate-feeding), instantaneous clearance rate $\left(g\right.$; number of prey $\left.\mathrm{l}^{-1} \mathrm{~s}^{-1}\right)$, clearance rate $\left(F\right.$; as volume swept clear in 1 min ${ }^{-1}$ ind. ${ }^{-1}$ ) and average swimming speed $\left(s w ; \mathrm{cm} \mathrm{s}^{-1}\right)$. Where filter-feeding was the feeding mode, the filtering efficiency $\left(\% F_{\text {max }}\right)$ is presented. Values in brackets: SD. Wild phytoplankton species were given in a single experiment (Expt 18). n.i.: not identified

\begin{tabular}{|c|c|c|c|c|c|c|c|c|}
\hline Prey & Mean length & Expt & ic & Mode & $g$ & $F$ & $s w$ & $\% F_{\text {max }}$ \\
\hline \multicolumn{9}{|l|}{ Cultured phytoplankton } \\
\hline \multirow[t]{2}{*}{ Skeletonema costatum } & $4(1)$ & 1 & $1.1 \mathrm{E}+08$ & $\mathrm{f}$ & 0.0022 & 0.08 & 23.5 & 23 \\
\hline & & 2 & $2.3 \mathrm{E}+08$ & $\mathrm{f}$ & 0.0022 & 0.08 & 23.1 & 23 \\
\hline \multirow[t]{2}{*}{ Tetraselmis suecica } & $12(1)$ & 3 & $1.7 \mathrm{E}+07$ & $\mathrm{f}$ & 0.0022 & 0.08 & 19.1 & 28 \\
\hline & & 4 & $8.2 \mathrm{E}+07$ & $\mathrm{f}$ & 0.0022 & 0.08 & 17.2 & 31 \\
\hline \multicolumn{9}{|l|}{ Cultured zooplankton } \\
\hline \multirow[t]{2}{*}{ Brachionus plicatilis } & $190(42)$ & 5 & 631 & $\mathrm{f}$ & 0.0096 & 0.36 & 28.2 & 83 \\
\hline & & 6 & 942 & $\mathrm{f}$ & 0.0096 & 0.36 & 29.4 & 79 \\
\hline \multirow[t]{6}{*}{ Artemia salina } & $592(61)$ & 7 & 667 & $\mathrm{f}$ & 0.0096 & 0.36 & 26.7 & 87 \\
\hline & $722(85)$ & 8 & 942 & $\mathrm{f}$ & 0.0096 & 0.36 & 26.6 & 88 \\
\hline & $724(29)$ & 9 & 942 & $\mathrm{f}$ & 0.0096 & 0.36 & 26.1 & 89 \\
\hline & $780(136)$ & 10 & 616 & $\mathrm{p}$ & 0.0175 & 0.66 & $32.7(10)$ & - \\
\hline & $828(84)$ & 11 & 852 & $\mathrm{p}$ & 0.0268 & 1.02 & $35.8(11)$ & - \\
\hline & $833(74)$ & 12 & 381 & $\mathrm{p}$ & 0.0175 & 0.66 & $33.1(10)$ & - \\
\hline \multicolumn{9}{|l|}{ Ichthyoplankton } \\
\hline \multirow{2}{*}{ Solea senegalensis eggs } & $1045(43)$ & 13 & 52 & $\mathrm{p}$ & 0.1340 & 5.07 & $32.0(9)$ & - \\
\hline & & 14 & 73 & $\mathrm{p}$ & 0.0300 & 1.14 & $33.3(10)$ & - \\
\hline Sparus aurata eggs & $1003(40)$ & 15 & 140 & $\mathrm{p}$ & 0.0110 & 0.42 & $30.6(10)$ & - \\
\hline Solea senegalensis larvae & $2470(250)$ & 16 & 40 & $\mathrm{p}$ & 0 & 0 & $24.8(6)$ & - \\
\hline Sparus aurata larvae & $3030(230)$ & 17 & 255 & $\mathrm{p}$ & 0.0639 & 2.43 & $33.7(7)$ & - \\
\hline Wild phytoplankton & & 18 & & & & & & \\
\hline Dinoflagellates & & & 607 & $\mathrm{f}$ & 0 & 0 & $21.9(6)$ & - \\
\hline Scripsiella spp. & $24(4)$ & & & & & & & \\
\hline Dinoflagellates n.i. & $24(4)$ & & & & & & & \\
\hline Protoperidinium sp. & $48(9)$ & & & & & & & \\
\hline Diatoms & & & 262 & & 0 & 0 & & \\
\hline Thalassionema sp & 48 & & & & & & & \\
\hline Chaetoceros sp. & 11 & & & & & & & \\
\hline
\end{tabular}

Skeletonema costatum and the Chlorophyta Tetraselmis suecica) at the same clearance rate $\left(0.081 \mathrm{fish}^{-1}\right.$ $\min ^{-1}$; Fig. 2). However, swimming speed was slightly higher when feeding on $S$. costatum compared with $T$. suecica, corresponding to a filtering efficiency of $23 \%$ for $S$. costatum and $28 \%$ for T. suecica.

Results of the experiment using wild phytoplankton (dominated by small dinoflagellates and diatom chains and having an average size of $30 \mu \mathrm{m}$ ) showed no significant decrease in prey density with time (when using either the total number of phytoplankton prey or for separate phytoplankton classes), most likely due to the very low initial phytoplankton concentration (800 cells $\mathrm{l}^{-1}$ ). The initial swimming speed after the introduction of food ( $t=10 \mathrm{~min}$ ) was slightly higher $\left(1.38 \pm 0.5[\mathrm{SD}] \mathrm{bl} \mathrm{s}^{-1}\right)$ than in experiments using cultured phytoplankton, although in this instance and in contrast to other experiments in which fish filter-fed, swimming speed decreased during the course of the experiment.

Clearance rates of sardines filter-feeding on cultured Brachionus plicatilis $(\sim 190 \mu \mathrm{m})$ and small Artemia salina $(\leq 724 \mu \mathrm{m})$ were the same at $0.36 \mathrm{fish}^{-1} \mathrm{~min}^{-1}$, higher than values obtained for fish feeding on phytoplankton. However, because the swimming speed of sardines feeding on $B$. plicatilis was higher than when feeding on $A$. salina (Fig. 3), this results in filtering efficiency of $80 \%$ for $B$. plicatilis and $90 \%$ for small $A$. salina. Overall, sardine filtering efficiency increased from the smallest prey used in these experiments (4 to $12 \mu \mathrm{m})$ up to $\sim 230 \mu \mathrm{m}$ where it reaches a plateau around $90 \%$, indicating that sardines are highly efficient in retaining particles above this size (Fig. 4).

Sardines particulate-fed on large zoo- and ichthyoplankton prey, which included cultured Artemia salina of $780 \mu \mathrm{m}$ and larger, indicating that the size at which sardine switches from filter- to particulate-feeding lies in the range 724 to $780 \mu \mathrm{m}$. Both the clearance rate $\left(0.66 \mathrm{lish}^{-1} \mathrm{~min}^{-1}\right)$ and swimming speed (average 32.7 to $35.8 \mathrm{~cm} \mathrm{~s}^{-1}$ ) of sardines particulate-feeding on large A. salina were higher than fish filter-feeding on small A. salina (Fig. 3).

The highest clearance rate and swimming speed was recorded for sardines particulate-feeding on fish eggs. 
Sardines particulate-fed in experiments where 3 different initial concentrations of fish eggs were used, with the highest clearance rate (5.07 1 fish $^{-1} \mathrm{~min}^{-1}$ ) being observed in the experiment that had the lowest initial concentration (Fig. 5). Additionally, swimming speed after the introduction of food was also higher, at
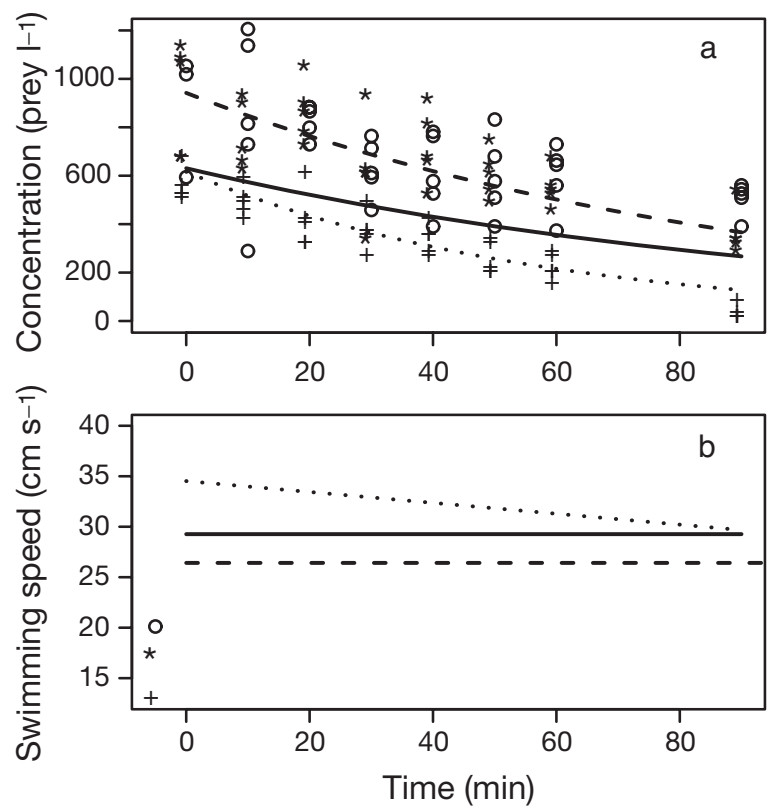

Fig. 3. Sardina pilchardus. Change in (a) food concentration and (b) swimming speed with time, for 3 experiments where Iberian sardines were fed on cultured zooplankton. Sardines filter-fed on Brachionus plicatilis ( ${ }^{*}$, dashed line) and Artemia salina $<780 \mu \mathrm{m}(\mathrm{O}$, solid line), and particulate-fed on Artemia salina $>780 \mu \mathrm{m}(+$, dotted line). Food concentration decrease was modelled by GLM, the slope of the fitted lines is the instantaneous grazing rate. Swimming speed vs. time was fitted by linear regression and symbols $\left({ }^{*}, 0,+\right)$ represent the non-feeding swimming speed prior to the addition of food

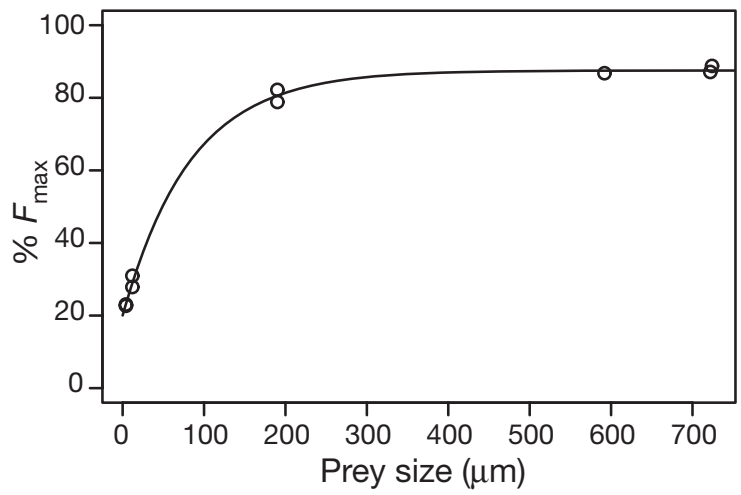

Fig. 4. Sardina pilchardus. Filtration efficiency as a function of particle size for filter-feeding. The fitted model is

$$
\% F_{\max }=20.02+3793\left[1-\exp \left(-\frac{\text { Prey size }}{83.37}\right)\right]
$$

the beginning of that experiment and decreased sharply as food concentration decreased, whereas for the other 2 experiments where initial egg density was higher, initial swimming speed was lower, and swimming speed did not change with time. Sardines feeding on Sparus aurata larvae, which distribute themselves in midwater and actively swim, showed a high clearance rate $\left(2.43 \mathrm{lfish}^{-1} \mathrm{~min}^{-1}\right)$ and high swimming speed $\left(33.7 \pm 7[\mathrm{SD}] \mathrm{cm} \mathrm{s}^{-1}\right)$, similar to the estimates obtained for experiment in which Solea senegalensis eggs were given in low concentrations. Conversely, when feeding on Solea senegalensis larvae which float at the surface, sardine showed only a small increase in fish swimming speed from non-feeding levels $(24.8 \pm 6$ [SD] $\mathrm{cm} \mathrm{s}^{-1}$ ), and neither filter nor particulate-feeding was observed during this experiment. No decrease in the concentration of these fish larvae through the experiment was detected by the model, indicating inefficient or unsuccessful feeding.

In general, the clearance rates and swimming speeds of particulate-feeding sardines were higher than for fish engaged in filter-feeding (Figs. 1 \& 6, Table 1). Since the feeding mode used by sardines is determined by prey size, both ingestion rates and initial swimming speeds of sardines feeding on large prey $(>780 \mu \mathrm{m})$

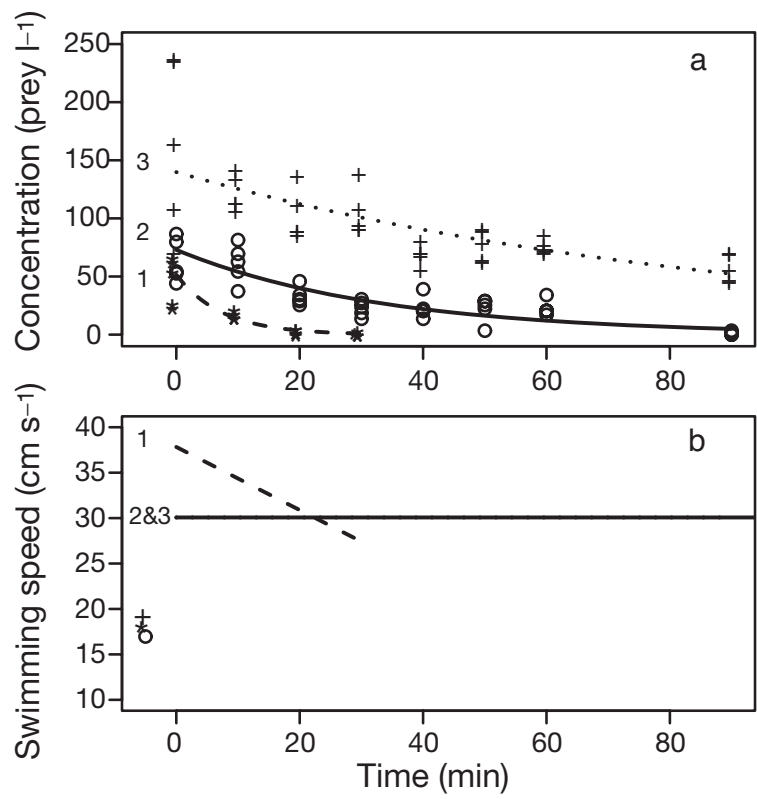

Fig. 5. Sardina pilchardus. Change in (a) food concentration and (b) swimming speed with time, for 3 experiments where Iberian sardine particulate-fed on fish eggs at different initial concentrations/numbers 1 ( + , dotted line), 2 ( $O$, solid line) of Solea senegalensis and $3\left({ }^{*}\right.$, dashed line) of Sparus aurata. Food concentration decrease was modelled by GLM, the slope of the fitted line is the instantaneous grazing rate. Swimming speed vs. time was fitted by linear regression and the symbols $\left({ }^{*}, O,+\right)$ represent the nonfeeding average swimming speed prior to the addition of food 
were higher than when feeding on prey smaller than $<724 \mu \mathrm{m}$ (Fig. 6). The clearance rate of filterfeeding sardines was related to prey size as a result of the increase in the filtering efficiency with increasing prey length (Fig. 2). However, fish swimming speed was not correlated with prey length but rather to the prey type, being lower while filter-feeding on phytoplankton and higher while filter-feeding on zooplankton (Table 1). Clearance rates and swimming speeds of filterfeeding sardines (above a certain concentration threshold) were not correlated to initial prey density. While particulate-feeding, clearance rates and swimming speeds of sardines were not related to prey size but to prey type (Table 1). The highest clearance rate and swimming speed were obtained with sardines preying on fish eggs, but both variables decreased when higher densities of this prey were used in the experiments (Fig. 5).
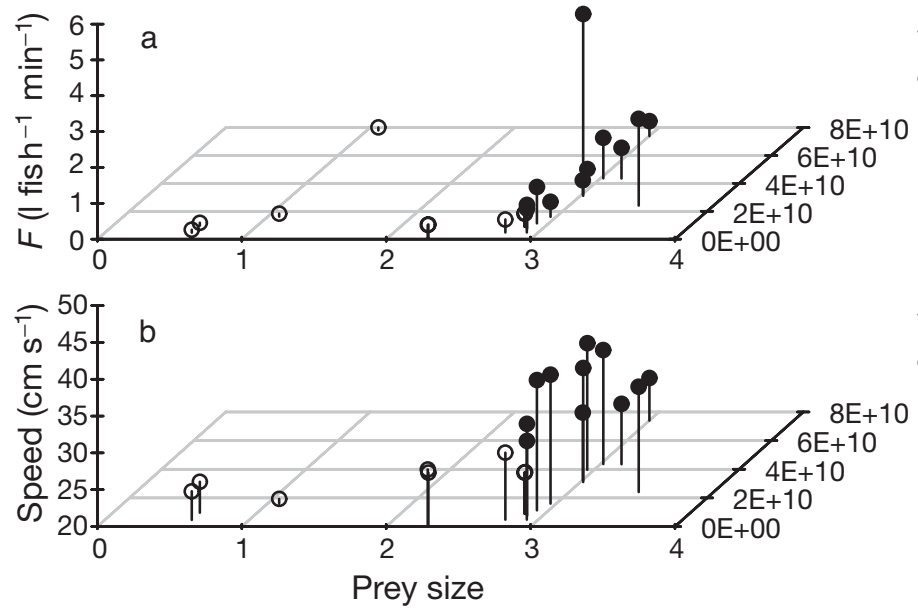

Fig. 6. Sardina pilchardus. Relationships between (a) prey size (shown as $\log _{10}$ of prey length, in $\mu \mathrm{m}$ ), initial prey biovolume (biov init) and clearance rate $(F)$ and (b) prey size, initial prey biovolume and swimming speed while filter-feeding $(O)$ and particulate-feeding $(\bullet)$ on cultured prey used in feeding experiments

\section{Mixed experiments: selectivity}

In all the experiments conducted to examine feeding selectivity (Tables $2 \& 3$ ) sardines particulate-fed only and no filter-feeding was observed. Even at high prey densities (Expts 20 to 22, Table 2), sardines particulatefed selectively, with fish eggs being depleted faster. Clearance rates of sardines preying on fish eggs ranged from 0.64 to $3.011 \mathrm{fish}^{-1} \mathrm{~min}^{-1}$, higher than the clearance rates for fish larvae $\left(0.23\right.$ to $\left.0.53 \mathrm{lish}^{-1} \mathrm{~min}^{-1}\right)$ and large Artemia salina ( 0.36 to $0.41 \mathrm{fish}^{-1} \mathrm{~min}^{-1}$ ) which indicates that sardine feeding selectivity is toward specific prey

Table 2. Sardina pilchardus. Feeding experiments in which mixed cultured prey types were used. Mean prey length $(\mu \mathrm{m})$ and initial concentration $\left(i c_{;}\right.$prey $\left.\mathrm{l}^{-1}\right)$ of mixed cultured prey types used in feeding experiments. The instantaneous clearance rate $(g)$ corresponds to the slope of the generalized linear model fitted to the decrease of prey concentration vs. time; $F$ is the clearance rate ( $\mathrm{fish}^{-1}$ $\left.\mathrm{min}^{-1}\right) ;$ and $s W$ is swimming speed $\left(\mathrm{cm} \mathrm{s}^{-1}\right)$. Values in brackets: SD

\begin{tabular}{|lccccc|}
\hline & Mean length & ic & $g$ & $F$ & SW \\
\hline Expt 19 & & & & & \\
Solea senegalensis eggs & $1045(43)$ & 77 & 0.0703 & 2.66 & $26.9(6)$ \\
Solea senegalensis larvae & $2470(249)$ & 29 & 0.0060 & 0.23 & \\
Expt 20 & & & & & \\
Artemia salina & $886(60)$ & 453 & 0.0108 & 0.41 & $29.7(8)$ \\
Sparus aurata eggs & $1003(40)$ & 53 & 0.0170 & 0.64 & \\
Expt 21 & & & & & \\
Tetraselmis suecica & $12(1)$ & $2.3 \mathrm{E}+07$ & 0.0039 & 0.15 & $27.5(9)$ \\
Artemia salina & $910(80)$ & 627 & 0.0108 & 0.41 & \\
Sparus aurata eggs & $1003(40)$ & 25 & 0.0482 & 1.82 & \\
Expt 22 & & & & & \\
Artemia salina & $923(86)$ & 973 & 0.0096 & 0.36 & $28(8)$ \\
Solea senegalensis eggs & $1045(43)$ & 24 & 0.0795 & 3.01 & \\
Sparus aurata larvae & $3029(225)$ & 66 & 0.0140 & 0.53 & \\
\hline
\end{tabular}

types and not the larger prey available. Comparison of the clearance rates obtained in single prey type experiments and those obtained in mixed assemblages reveals that fish eggs were cleared at rates within the range of those obtained in single experiments. Similarly, both $A$. salina and Sparus aurata larvae were cleared at comparable rates in single and mixed prey experiments. On the other hand, Solea senegalensis larvae, which were apparently ignored in experiments using a single food type, had a clearance rate of $0.231 \mathrm{fish}^{-1} \mathrm{~min}^{-1}$ when given in a mixture with Solea senegalensis eggs, probably as a result of incidental capture. Feeding selectivity was also observed in experiments using mixed assemblages of wild plankton where the initial food concentration was low (Table 3). The higher clearance rates observed for copepods and decapods $(0.73$ to $0.861 \mathrm{fish}^{-1} \mathrm{~min}^{-1}$ ) indicate that these items were preferred to gelatinous plankton $\left(F=0.35\right.$ to $\left.0.40 \mathrm{l} \mathrm{fish}^{-1} \mathrm{~min}^{-1}\right)$. This again indicates that prey size is not the only determinant of prey selection since the gelatinous plankton were larger than the copepods. Sardines fed on dinoflagellates, diatoms and crustacean eggs with similar clearance rates (0.011 l fish $\left.{ }^{-1} \mathrm{~min}^{-1}\right)$.

\section{DISCUSSION}

This study has shown that adult Sardina pilchardus use 2 different feeding modes: filter-feeding on small 
Table 3. Sardina pilchardus. Feeding experiments in which mixed wild prey types were used. Mean prey length $(\mu \mathrm{m})$ and initial concentration $\left(i c\right.$; prey $\mathrm{l}^{-1}$ ). The instantaneous clearance rate $(g)$ corresponds to the slope of the generalized linear model fitted to the decrease of prey concentration vs. time; $F$ is the clearance rate $\left(\mathrm{fish}^{-1} \mathrm{~min}^{-1}\right)$; and $\mathrm{sw}$ is swimming speed $\left(\mathrm{cm} \mathrm{s}^{-1}\right)$. Values in brackets: SD

\begin{tabular}{|lrrccc|}
\hline Prey & $\begin{array}{c}\text { Mean } \\
\text { length }\end{array}$ & ic & $g$ & $F$ & $s W$ \\
\hline Expt 23 & & & & & \\
Crustacean eggs & 250 & 90 & 0.0060 & 0.23 & $30.2(9)$ \\
Copepods & 1070 & 43 & 0.0227 & 0.86 & \\
Decapods & 2230 & 2 & 0.0227 & 0.86 & \\
Gelatinous plankton & 1398 & 10 & 0.0092 & 0.35 & \\
Expt 24 & & & & & \\
Dinoflagellates & 30 & 560 & 0.0107 & 0.40 & $24.3(6)$ \\
Diatoms & 80 & 346 & 0.0107 & 0.40 & \\
Crustacean eggs & 115 & 42 & 0.0107 & 0.40 & \\
Calanoids & 884 & 12 & 0.0192 & 0.73 & \\
Doliolids & 993 & 8 & 0.0107 & 0.40 & \\
& & & & & \\
\hline
\end{tabular}

( $\leq 724 \mu \mathrm{m})$ prey and particulate-feeding for large $(\geq 780 \mu \mathrm{m})$ prey or mixed assemblages of both small and large prey. The feeding mode selection depends exclusively on prey size and is not related to prey density. The ability to use these 2 feeding modes has been described for several clupeids, among which Iberian sardines appear similar to the Cape anchovy Engraulis encrasicolus, which also switches to particulate feeding at a relatively small prey size of around $720 \mu \mathrm{m}$, irrespective of prey density (James \& Findlay 1989). This is in contrast to southern Benguela sardine Sardinops sagax, a species that changes from filter- to particulate-feeding at larger prey sizes (3060 $\mu \mathrm{m}$ for cultured and $1310 \mu \mathrm{m}$ for wild plankton; van der Lingen 1994) and filter-feeds on large prey if these are present in high concentrations (van der Lingen 1994), and also other clupeids like herring Clupea harengus and mackerel Scomber japonicus whose feeding mode choice depends exclusively on prey density (O'Connell \& Zwifel 1972, Batty et al. 1990).

Iberian sardines can retain particles as small as $4 \mu \mathrm{m}$ (i.e. nanoplankton), as shown in experiments using cultured phytoplankton (Fig. 1), albeit with a relatively low filtering efficiency of $20 \%$ (Fig. 4). The filtering efficiency of Iberian sardines for small prey (23\% for 4 to $12 \mu \mathrm{m}$ prey) was similar to that shown by the obligate filter-feeder Brevoortia tyrannus (16.5\% for $12 \mu \mathrm{m}$ prey, Durbin \& Durbin 1975), and higher than that shown by Engraulis encrasicolus which only retain particles larger than $90 \mu \mathrm{m}$ (James \& Findlay 1989) and by Sardinops sagax which had a filtering efficiency of $2 \%$ for particles of 13 to $17 \mu \mathrm{m}$. However, the reference value of maximum clearance rate calculated for Sardina sagax by van der Lingen (1994) was much higher than for Sardina pilchardus, since both mouth gape and swimming speed while filter-feeding of the former approximately double the values observed for Sardina pilchardus in this study. Previous stomach content analyses have indicated that the smallest prey retained by sardines was around $50 \mu \mathrm{m}$ (Varela et al. 1988, Garrido 2003). However, small (2 to $20 \mu \mathrm{m}$ ) phytoplankton groups such as cocolithophores that have no resistant exteriors (in contrast to the silica test of diatoms and the carbonate skeleton of some dinoflagellates), may be ingested by sardines but difficult to identify because of rapid digestion by acids in the stomach. Given that nanoplankton species can frequently dominate primary production in upwelling systems such as the NE Iberian coast (e.g. Tilstone et al. 2003, Varela et al. 2003, Lorenzo et al. 2005) and that there are toxic species among nanoplankton that might affect fish behaviour and/or survival (Rodger et al. 1994, Wiegand \& Pfulgmacher 2005), its importance in the sardines' diet should be further examined.

The clearance rate for Tetraselmis suecica was not statistically different between the mixed assemblage experiment $\left(0.15 \mathrm{l} \mathrm{fish}{ }^{-1} \mathrm{~min}^{-1}\right)$ when fish were particulate-feeding, and the single prey experiment (0.08 l fish $^{-1} \mathrm{~min}^{-1}$ ) when fish were filter-feeding. This suggests that the shorter period that sardines spent with an open mouth whilst engaged in particulate-feeding was compensated for by their higher swimming speed. In other words, the clearance rates of small prey are similar whether they are obtained by incidental capture during particulate-feeding on larger prey items or obtained by filtering.

Filtration efficiency became close to maximum (>80\%) with prey larger than $200 \mu \mathrm{m}$ (Fig. 4), which allows Iberian sardines to efficiently utilize all microplankton prey that dominate plankton abundance and sometimes biomass in coastal areas (Calbet et al. 2001, Turner 2004). This result is consistent with the composition of sardine stomach contents collected off the Portuguese coast which are volumetrically dominated by crustacean naupliar stages and small copepods, and numerically dominated by microplankton, especially chain-forming diatoms that can account for $99 \%$ of the of prey ingested during spring upwelling events (Garrido 2003). The dominance of microplankton in sardine stomachs suggests that filter-feeding is frequently used by sardines. This species appears to be welladapted for filter-feeding compared to other clupeids because the small mesh of the gill-rakers means that Iberian sardines are able to retain small plankton, and this species also possesses one of the largest epibranchial organs (which is responsible for the concentration of food items from the gill rakers) among clupeids (Bode et al. 2003). However, the relatively short average feeding act duration $(0.5 \mathrm{~s})$ shown by sardines 
when filter-feeding contrasts with previous suggestions that filter-bout duration is related to the degree of development of the epibranchial gland (van der Lingen 1994). According to that theory, species that lack an epibranchial gland would show bouts of short duration whereas obligate filter-feeders that have well-developed glands show long, almost continuous, filtering bouts.

Clearance rates obtained for sardines in these experiments were low during both filter- and particulatefeeding compared to results obtained in similar experiments conducted on other clupeids. The major reasons for this are the smaller mouth gape and lower swimming velocity of Iberian sardines (maximum observed swimming speed of $38 \mathrm{~cm} \mathrm{~s}^{-1}$ ) compared to other clupeids; Atlantic menhaden of $260 \mathrm{~mm}$ swam at speeds of up to $65 \mathrm{~cm} \mathrm{~s}^{-1}$ during filter-feeding (Durbin \& Durbin 1975), as did southern Benguela sardine of $230 \mathrm{~mm}$ (van der Lingen 1994), whereas Cape anchovy of $120 \mathrm{~mm}$ reached speeds of $55 \mathrm{~cm} \mathrm{~s}^{-1}$ (James \& Findlay 1989). A degree of caution must be used when comparing clearance rates between species, since differences in techniques and analyses employed may have a strong impact on results obtained. For example, clearance rates for Sardinops sagax were calculated using estimates of feeding intensity (the mean number of fish observed with open mouths at regular intervals during an experiment) whereas the total number of fish in the experimental tank was used in this study to estimate $F$, since in these experiments all sardines appeared to be engaged in feeding at the same time using the same feeding mode. Even if clearance rates in this study were calculated using the percentage of time sardines spent with their mouths open during each experiment (which is assumed to be similar to the calculation of feeding intensity), the clearance rates would still be substantially lower than those of $S$. sagax and other clupeids.

Clearance rate increased with prey length and was especially high when fish eggs were used as prey, particularly if provided at low densities. Prey density had no effect on the feeding mode used by sardines or on clearance rates during filter-feeding. On the other hand, prey density affected both clearance rates and swimming speeds when particulate-feeding on a particular prey type, since both parameters increased with decreasing densities of food organisms (as shown in the single prey-type experiments using single fish eggs).

Sardines generally removed larger prey at higher rates than small prey when feeding on a mixture of different sized organisms, which is indicative of selective feeding. When given in mixed assemblages fish eggs were preferred to all other prey, even larger fish larvae. Feeding selectivity was also observed in experi- ments using wild prey organisms, and again feeding selectivity was not exclusively related to prey size, since copepods were preferred to the larger doliolids and other gelatinous plankton. Selective feeding by planktivorous fish can have a marked impact on plankton communities (Brooks \& Dodson 1965, James \& Findlay 1989), both through the removal of particular zooplankton species (Koslow 1981) but also via predation on their own eggs and larvae (i.e. cannibalism) or of other species.

The clearance rate of sardines engaged in filterfeeding mostly depends on prey size, and is associated with different filtering efficiencies for differently sized prey. While particulate-feeding, however, clearance rate depends on factors other than prey size or prey biomass. It is likely that a complex relationship exists between predator and prey during particulate-feeding (Lazzaro 1987) that is affected by prey detectability (itself a function of shape, colour, chemical properties such as taste and smell, and motion), previous experience with that particular prey and differential escape abilities of prey. Fish eggs are motionless, as opposed to the other large prey that sardines particulate-fed on, and this is likely to have increased their vulnerability to capture compared to mobile prey that are able to escape predators. On the other hand, prey mobility may increase detectability; sardines avidly pursued the highly mobile Sparus aurata larvae but not Solea senegalensis larvae that barely moved and were positioned near to the water's surface. Sources of variation impacting on the feeding behaviour of Sardina pilchardus, such as selectivity unrelated to prey size, the effect of prey density, and the ambient prey composition, illustrate some of the difficulties in assigning clearance rate values for a given assemblage of food. However, this kind of information is essential for the construction of trophic models for coastal areas.

This study has provided important knowledge of the feeding behaviour of Sardina pilchardus, which will allow recognition of favourable feeding conditions for this species. Iberian sardine has a highly efficient filtering mechanism, and is able to retain the smallest food particles yet described for studies of this type. This ability of sardines (including both $S$. pilchardus and Sardinops sagax) to utilize very small particles, together with their well developed migration capabilities and serial spawning habits, have been suggested as characteristics that enable sardines to feed and spawn under conditions of relatively low productivity, and hence seek out environmental loopholes in predation fields that may not be available to anchovy, which are not able to entrap small prey and have reduced migratory capabilities compared to sardine (Bakun \& Broad 2003). On the other hand, sardines also seem to be well adapted to feed on large plankton particles, and be- 
have in a similar manner to species that are primarily particulate-feeders such as Engraulis mordax and Engraulis encrasicolus, namely particulate-feeding at high food densities of large prey and with mixtures of several prey sizes. This fact shows the extremely opportunistic feeding behaviour of Iberian sardines, which are highly adapted to different feeding conditions. We propose that, contrary to what was formerly thought, particulate-feeding may be frequently used by sardines, at least during the day, preying directly on bigger organisms if encountered. Although several experiments revealed the high visual acuity of several clupeids, that are able to particulate feed during bright moonlight nights, particulate feeding is proposed to be a visual predation, therefore it is not possible to occur during dark nights. Therefore, during the period of the night, when a visual predation is not possible or when large prey are scarce, sardines are able to filter feed on small prey with high filtering efficiencies. In fact, empty sardine stomachs have not yet been detected in our studies (Garrido 2003, Cunha et al. 2005) that involved a large number of individuals collected at night. However, feeding mode shifts also depend on energetic output, and experiments to examine the relative energetic costs of each feeding mode, as have been conducted for Cape anchovy (James \& Probyn 1989) and Benguela sardine (van der Lingen 1995), should be done on Iberian sardine in order to permit the construction of energetic models for this species.

Acknowledgements. This work was part of the IPIMAR Programme PELAGICOS, funded by the Portuguese Ministry of Science (MLE 013/2000), which also provided a research grant to S.G. We are grateful to Y. Stratoudakis, coordinator of PELAGICOS, for his comments on the manuscript and guidance on data analysis; and to P. Pousão-Ferreira, Director of the Aquaculture Station and all the personnel, for advice in the laboratory and apparatus assembly. We thank M. Neves dos Santos for providing the video camera, CRIP Sul Tavira for the supply of cultured phytoplankton and F. Quintela, G. Vilarinho, A. Morais, M. Morais, S. Palma and A. Silva for their help on phytoplankton and zooplankton identification. We thank the 4 anonymous reviewers for suggestions on the manuscript.

\section{LITERATURE CITED}

Bakun A, Broad K (2003) Environmental 'loopholes' and fish population dynamics: comparative pattern recognition with focus on El Niño effects in the Pacific. Fish Oceanogr 12:458-473

Batty RS, Blaxter JHS, Richard JM (1990) Light intensity and the feeding behaviour of herring Clupea harengus. Mar Biol 107:383-388

Bode A, Carrera P, Lens S (2003) The pelagic foodweb in the upwelling ecosystem of Galicia (NW Spain) during spring: natural abundance of stable carbon and nitrogen isotopes. ICES J Mar Sci 60:11-22

Bode A, Alvarez-Ossorio MT, Carrera P, Lorenzo J (2004) Reconstruction of the trophic pathways between plankton and the North Iberia sardine (Sardina pilchardus) using stable isotopes. Sci Mar 68:165-178

Borges MF, Santos AMP, Crato N, Mendes H, Mota B (2003) Sardine regime shifts off Portugal: a time series analysis of catches and wind conditions. Sci Mar 67(Suppl 1):235-244

Brooks JL, Dodson SI (1965) The effect of a marine planktivore on lake plankton illustrates theory of size, competition, and predation. Science 150:28-35

Calbet A, Garrido S, Saiz E, Alcaraz M, Duarte CM (2001) Annual zooplankton succession in coastal NW Mediterranean waters: the importance of the smaller size fractions. J Plankton Res 23:319-331

Costa PR, Garrido S (2004) Domoic acid accumulation in the sardine Sardina pilchardus and its relationship to Pseudonitzschia diatom ingestion. Mar Ecol Prog Ser 284: 261-268

Cunha ME, Garrido S, Pissarra J (2005) The use of stomach fullness and colour indices to assess Sardina pilchardus feeding. J Mar Biol Assoc UK 85:425-431

Durbin AG, Durbin EG (1975) Grazing rates of Atlantic menhaden Brevoortia tyrannus as a function of particle size and concentration. Mar Biol 33:265-277

Friedland KD, Haas LW, Merriner JV (1984) Filtering rates of the juvenile Atlantic menhaden Brevoortia tyrannus (Pisces: Clupeidae), with consideration of the effects of detritus and swimming speed. Mar Biol 84:109-117

Garrido S (2003) Alimentação de Sardina pilchardus (Walbaum, 1792) ao largo da costa continental portuguesa e implicações da condição nutricional das fêmeas na qualidade dos oócitos. MS thesis, Instituto de Ciências Biomédicas de Abel Salazar (ICBAS), Porto

Gibson RN, Ezzi IA (1990) Relative importance of prey size and concentration in determining the feeding behaviour of the herring Clupea harengus. Mar Biol 107:357-362

Gibson RN, Ezzi IA (1992) The relative profitability of particulate-feeding and filter-feeding in the herring, Clupea harengus L. J Fish Biol 40:577-590

Grant WS, Bowen BW (1998) Shallow population histories in deep evolutionary linkages of marine fishes: insights from sardines and anchovies and lessons for conservation. J Hered 89:415-426

Guisande C, Vergara AR, Riveiro I, Cabanas JM (2004) Climate change and abundance of the Atlantic-Iberian sardine (Sardina pilchardus). Fish Oceanogr 13:91-101

Harvey WH (1937) Note on selective feeding by Calanus. J Mar Biol Assoc UK 22:97-100

ICES (2006) Report of the working group on the assessment of mackerel, horse mackerel, sardine and anchovy. International Council for the Exploration of the Sea (CM Papers and Reports) CM 2006/ ACFM 08:631

James AG, Findlay KP (1989) Effect of particle size and concentration on feeding-behaviour, selectivity and rates of food ingestion by the Cape anchovy Engraulis capensis. Mar Ecol Prog Ser 50:275-294

James AG, Probyn T (1989) The relationship between respiration rate, swimming speed and feeding behaviour in Cape anchovy Engraulis capensis Gilchrist. J Exp Mar Biol Ecol 131:81-100

Janssen J (1976) Feeding modes and prey size selection in alewife (Alosa pseudoharengus). J Fish Res Board Can 33: 1972-1975

Koslow JA (1981) Feeding selectivity of schools of northern anchovy, Engraulis mordax, in the southern California bight. Fish Bull 79:131-142

Lazzaro X (1987) A review of planktivorous fishes - their evolution, feeding behaviours, selectivities, and impacts. Hydrobiol 146:97-167 
Leong RJH, O'Connell CP (1969) A laboratory study of particulate and filter feeding of northern anchovy (Engraulis mordax). J Fish Res Board Can 26:557-582

Lorenzo LM, Arbones B, Tilstone GH, Figueiras FG (2005) Across-shelf variability of phytoplankton composition, photosynthetic parameters and primary production in the NW Iberian upwelling system. J Mar Syst 54:157-173

Mathisen OA, Thorne RE, Trumble RJ, Blackburn M (1978) Food consumption of pelagic fish in an upwelling area. In: Boje R, Tomczak M (eds) Upwelling ecosystems. SpringerVerlag, New York, p 111-123

O'Connell CP, Zweifel JR (1972) Laboratory study of particulate and filter feeding of pacific mackerel, Scomber japonicus. Fish Bull 70:973-981

Parrish RH, Nelson CS, Bakun A (1981) Transport mechanisms and reproductive success of fishes in the California current. Biol Oceanogr 1:175-203

Peleteiro B, Marçalo A, Olmedo M, Pousão-Ferreira P, Garrido S, Porteiro C, Stratoudakis Y (2004) Sardine tagging off the Iberian Peninsula: laboratory experiments and operations at sea. ICES ASC CM 2004/Q20

R Development Core Team (2005) R: a language and environment for statistical computing. R Foundation for Statistical Computing, Vienna, Austria. Available at: www.Rproject.org

Rodger HD, Turnbull T, Edwards C, Codd GA (1994) Cyanobacterial (blue-green algal) bloom associated pathology in brown trout, Salmo trutta L., in Loch Leven, Scotland. J Fish Dis 17:177-181

Schwartzlose RA, Alheit J, Bakun A, Baumgartner TR and 17 others (1999) Worldwide large-scale fluctuations of sardine and anchovy populations. S Afr J Mar Sci 21:289-347

Stratoudakis Y, Bernal M, Borchers DL, Borges MF, Cardador F (2003) Changes in the distribution of sardine eggs and larvae off Portugal, 1985-2000. Fish Oceanogr 12:49-60

Editorial responsibility: Otto Kinne (Editor-in-Chief), Oldendorf/Luhe, Germany
Tilstone GH, Figueiras FG, Lorenzo LM, Arbones B (2003) Phytoplankton composition, photosynthesis and primary production during different hydrographic conditions at the Northwest Iberian upwelling system. Mar Ecol Prog Ser 252:89-104

Turner JT (2004) The importance of small planktonic copepods and their roles in pelagic marine food webs. Zool Studies 43:255-266

van der Lingen CD (1994) Effect of particle size and concentration on the feeding behaviour of adult pilchard Sardinops sagax. Mar Ecol Prog Ser 109:1-13

van der Lingen CD (1995) Respiration rate of adult pilchard Sardinops sagax in relation to temperature, voluntary swimming speed and feeding behaviour. Mar Ecol Prog Ser 129:41-54

Varela M, Larrañaga A, Costas E, Rodríguez B (1988) Contenido estomacal de la sardina (Sardina pilchardus, Walbaum) durante la campaña Saracus 871 en las plataformas Cantábrica y de Galicia en Febrero de 1987. Bol Inst Esp Oceanogr 5:17-28

Varela M, Alvarez-Ossorio MT, Valdés L (1990) Método para el estudio cuantitativo del contenido estomacal de la sardina. Resultados preliminares. Bol Inst Esp Oceanogr 6: $117-126$

Varela MM, Barquero S, Bode A, Fernández E, González N, Teira E (2003) Microplanktonic regeneration of ammonium and dissolved organic nitrogen in the upwelling area of the NW of Spain: relationships with dissolved organic carbon production and phytoplankton size-structure. J Plankton Res 25:719-736

Venables WN, Ripley BD (2002) Modern applied statistics with $\mathrm{S}, 4$ th edn. Springer, New York

Wiegand C, Pflugmacher S (2005) Ecotoxicological effects of selected cyanobacterial secondary metabolites a short review. Toxicol Appl Pharmacol 203:201-218

Submitted: February 1, 2006; Accepted: June 12, 2006 Proofs received from author(s): January 15, 2007 